\title{
NF- $\kappa B$ and Human Cancer: What Have We Learned over the Past 35 Years?
}

\author{
Thomas D. Gilmore (D)
}

Citation: Gilmore, T.D. NF- $\kappa$ B and Human Cancer: What Have We Learned over the Past 35

Years? Biomedicines 2021, 9, 889 .

https://doi.org/10.3390/

biomedicines 9080889

Academic Editor: Veronique Baud

Received: 23 June 2021

Accepted: 22 July 2021

Published: 25 July 2021

Publisher's Note: MDPI stays neutral with regard to jurisdictional claims in published maps and institutional affiliations.

Copyright: (C) 2021 by the author. Licensee MDPI, Basel, Switzerland. This article is an open access article distributed under the terms and conditions of the Creative Commons Attribution (CC BY) license (https:// creativecommons.org/licenses/by/ $4.0 /)$.
Biology Department, Boston University, Boston, MA 02215, USA; gilmore@bu.edu

\begin{abstract}
Transcription factor NF- $\mathrm{KB}$ has been extensively studied for its varied roles in cancer development since its initial characterization as a potent retroviral oncogene. It is now clear that NF- $\kappa \mathrm{B}$ also plays a major role in a large variety of human cancers, including especially ones of immune cell origin. NF- $\kappa \mathrm{B}$ is generally constitutively or aberrantly activated in human cancers where it is involved. These activations can occur due to mutations in the NF- $k B$ transcription factors themselves, in upstream regulators of NF- $\kappa B$, or in pathways that impact NF- $\kappa B$. In addition, NF- $k B$ can be activated by tumor-assisting processes such as inflammation, stromal effects, and genetic or epigenetic changes in chromatin. Aberrant NF- $\mathrm{KB}$ activity can affect many tumor-associated processes, including cell survival, cell cycle progression, inflammation, metastasis, angiogenesis, and regulatory $\mathrm{T}$ cell function. As such, inhibition of NF- $\mathrm{kB}$ has often been investigated as an anticancer strategy. Nevertheless, with a few exceptions, NF-kB inhibition has had limited success in human cancer treatment. This review covers general themes that have emerged regarding the biological roles and mechanisms by which NF- $\mathrm{BB}$ contributes to human cancers and new thoughts on how NF- $\mathrm{B}$ may be targeted for cancer prognosis or therapy.
\end{abstract}

Keywords: NF-kappaB; cancer; therapy; immunity; signal transduction

\section{Introduction}

Eukaryotic transcription factor NF-кB (nuclear factor kappa-light-chain-enhancer of activated B cells) has been the subject of intense study over the past 35 years for its role in a variety of normal and pathological processes [1]. Indeed, there are currently approximately 100,000 publications with information related to NF- $\mathrm{KB}$. After providing some basic information on NF- $\mathrm{BB}$ protein structure and signaling, this review features a historical and conceptual overview of NF- $\mathrm{kB}$ signaling and human cancer, as well as therapeutic implications. This review is meant to serve as a broad introduction to more specific articles on NF- $\mathrm{KB}$ and cancer which are included in this dedicated issue of Biomedicines.

\subsection{Structures of $N F-\kappa B$ and $I \kappa B$ Proteins}

In humans, the NF-кB superfamily comprises five transcription factors: REL (also known as c-Rel), RELA (also known as p65), RELB, NFKB1 (p105), and NFKB2 (p100) [2]. These proteins are related on the basis of a conserved N-terminal domain called the Rel homology domain (RHD), which contains residues important for DNA binding, dimerization, and nuclear localization. Based on the extent of amino acid sequence similarity within the RHD and protein domains C-terminal to the RHD, the NF- $\mathrm{kB}$ superfamily is usually divided into two subfamilies: the Rel proteins (REL, RELA, RELB) and the NF- $\kappa B$ proteins (p100 and p105). The Rel family proteins have C-terminal transactivation domains, whereas the NF- $\mathrm{B}$ B proteins have C-terminal ankyrin (ANK) repeat domains. For the most part, all five NF- $\mathrm{B}$ B superfamily proteins can form all combinations of heterodimers, as well as homodimers. Although generally activators of transcription, in some situations, $\mathrm{NF}-\kappa \mathrm{B}$ dimers repress transcription of target genes. Whether a given NF- $\mathrm{B}$ dimer can activate or repress transcription can depend on the DNA site it binds to or its interaction 
with different cofactors or other transcription factors at a given transcriptional regulatory site [3]. Moreover, NF-KB transcription factors can interact with DNA regulatory elements indirectly due to interactions with other transcription factors that are bound to DNA [4].

The activity of all NF- $\mathrm{KB}$ dimers is modulated by interaction with a family of NF- $\mathrm{KB}$ inhibitor proteins called I $\kappa$ Bs [5]. All I $\kappa B$ proteins consist of a series of 5-8 ANK repeats, which are protein interaction domains that interact with the RHD sequences and block the ability of NF- $\mathrm{kB}$ dimers to bind to DNA and translocate to the nucleus. There are several independent I $\mathrm{K} B$ proteins $(\mathrm{I} \kappa \mathrm{B} \alpha,-\beta,-\varepsilon, \mathrm{BCL} 3)$ which have different cell type-specific expression and have different affinities for the different NF- $\mathrm{kB}$ dimers. In addition, the C-terminal sequences of p100 and p105 contain ANK repeat IкB sequences that interact intramolecularly with the RHD sequences to block their activity. The general structures of NF- $\mathrm{kB}$ and IкB proteins are shown in Figure 1.

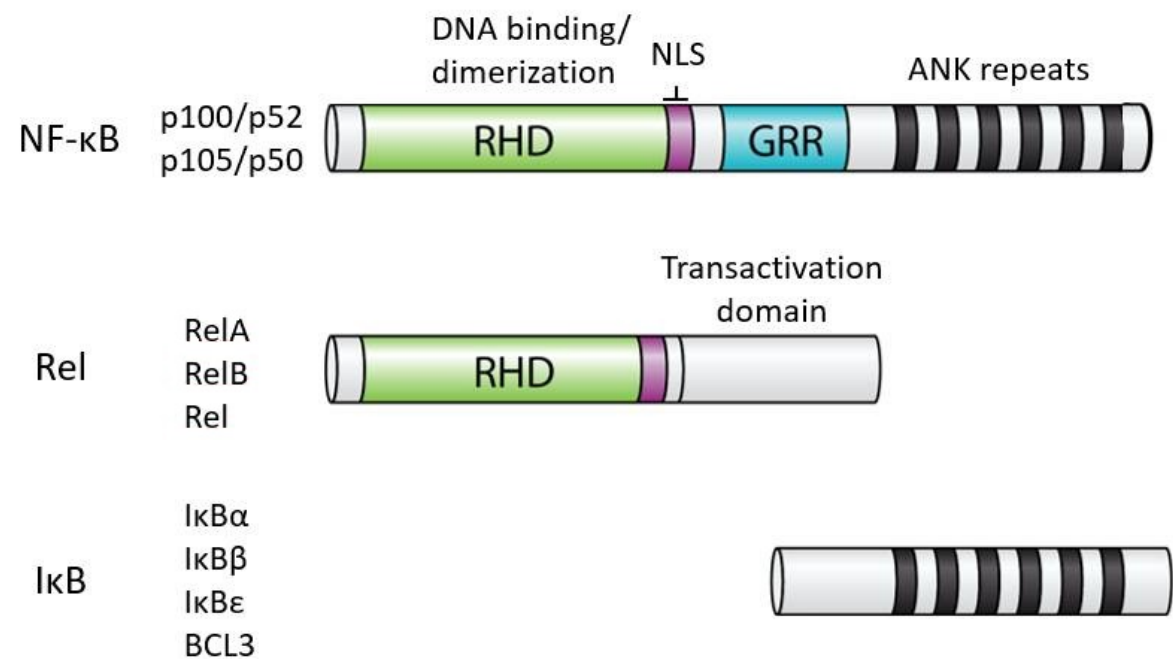

Figure 1. General structures of NF- $\kappa B$ and I $\kappa B$ proteins. Shown are the general structures of human NF- $\kappa \mathrm{B}$ and Rel proteins, as well as I $\mathrm{B}$ p proteins (i.e., I $\mathrm{KB} \alpha, \mathrm{I} \kappa \mathrm{B} \beta, \mathrm{I} \kappa \mathrm{B} \varepsilon$, BCL3). RHD, Rel homology domain; NLS, nuclear localization sequence; GRR, glycine-rich region; ANK, ankyrin repeats (black bars). The details of the indicated protein domains are described in the text.

\subsection{Activation of NF- $\kappa B$ Dimers Involves Nuclear Translocation}

In most basal situations, NF- $\kappa B-I \kappa B$ complexes are located in the cytoplasm [5]. Activation of NF- $\kappa B$ involves signal-induced degradation of the I $\kappa B$ protein, which frees $\mathrm{NF}-\mathrm{kB}$ to enter the nucleus to affect gene transcription. The primary regulators of I $\kappa \mathrm{B}$ stability are two kinases known as IкB kinases (IKK) $\alpha$ and $\beta$. These two kinases regulate two primary NF- $\mathrm{kB}$ activation pathways called the canonical and noncanonical NF- $\kappa B$ pathways (Figure 2). Thus, the core NF-kB signaling pathway consists of NF- $k B$ dimers, IKB proteins, and IKKs.

In the canonical pathway, IкB $\alpha$ bound to an NF- $\mathrm{BB}$ dimer (e.g., p50-RELA, p50REL) is phosphorylated by IKK $\beta$, which induces ubiquitination and proteasome-mediated degradation of $I \kappa B \alpha[5]$. In the noncanonical pathway, a p100-RELB dimer undergoes induced degradation of the p100 C-terminal sequences to become p52-RELB [6]. That is, following IKK $\alpha$-mediated phosphorylation of serine residues in the C-terminal half of $\mathrm{p} 100$, there is proteasomal processing of the ANK repeats to generate p52 from p100. In both the canonical and noncanonical pathways, the NF-kB dimer (e.g., p50-RELA or p52-RELB, respectively) can enter the nucleus and bind to DNA. There are many subtle differences in NF- $\mathrm{KB}$ signaling and activation in different cell types and depending on the given NF- $\kappa \mathrm{B}-\mathrm{I} \kappa \mathrm{B}$ complex involved, but those details are beyond the scope of this review. 


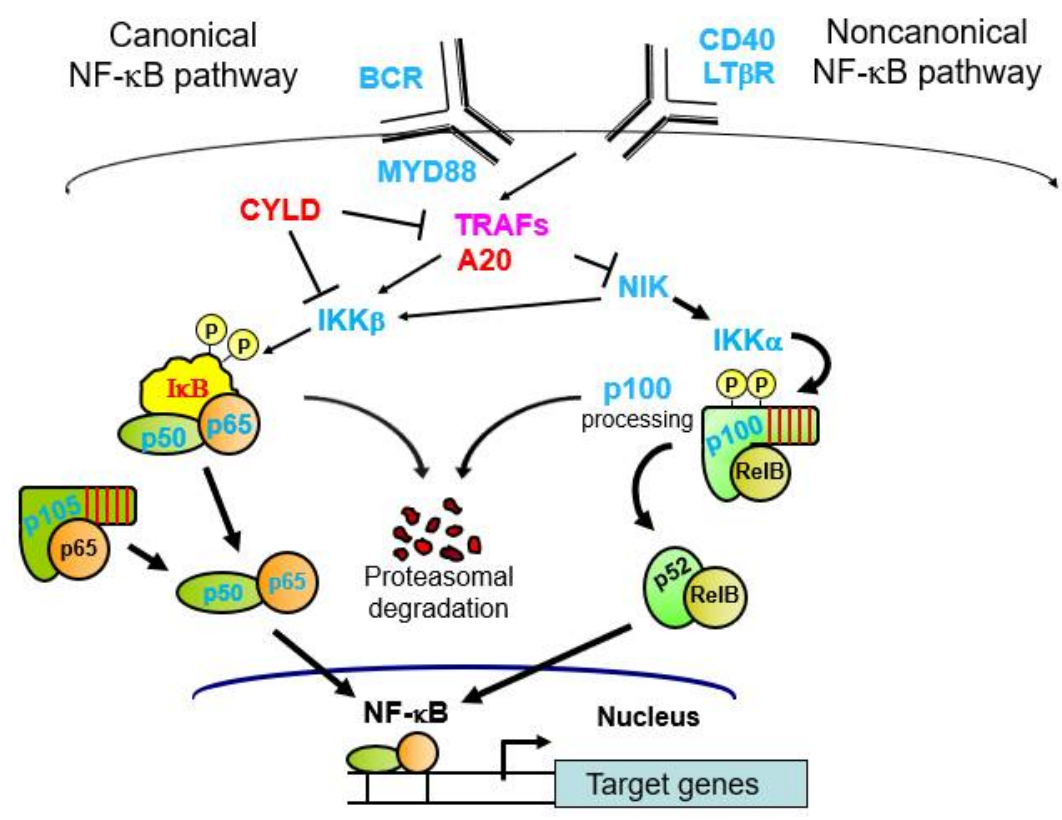

Figure 2. Canonical and noncanonical NF- $\kappa B$ pathways. Shown are the two most common NF- $\mathrm{kB}$ pathways, including several of the pathway components that are affected by mutations in cancer. Blue font, affected by gain-of-function mutations; red font, affected by loss-of-function mutations; purple font, affected by both gain- and loss-of-function mutations. See text for more details.

\subsection{Upstream Pathways That Lead to Activation of NF-kB}

There are over 300 different signals that are now known to activate IKK proteins to cause downstream activation of NF-kB (see nf-kb.org). In many cases, the ultimate upstream activators are receptor-like proteins that bind to ligands [5]. Ligand binding to the receptor then initiates a multicomponent signaling pathway that leads to activation of a given IKK complex and a downstream NF-kB pathway.

\subsection{Signal-Induced Activation of NF- $\kappa B$}

Two types of well-studied upstream activators of canonical NF- $\mathrm{kB}$ signaling are cytokine receptors (e.g., tumor necrosis factor (TNF), interferons, interleukins (ILs)) [7] and pathogen receptors (e.g., Toll-like receptors (TLRs) or cGAS-STING complexes) [8-10]. The most common activators of noncanonical NF- $\mathrm{KB}$ signaling are the $\mathrm{B}$ cell activating factor (BAFF), the cell surface receptor CD40, and the lymphotoxin- $\beta$ receptor [6]. Nevertheless, there is much overlap between the two pathways, and several ligands that induce activation of NF- $\mathrm{KB}$ can activate both the canonical and noncanonical pathways, even in the same cell type [6]. In almost all cases, cancer-related effects on NF- $\mathrm{kB}$ involve an alteration that causes chronic activation of nuclear canonical or noncanonical NF- $\mathrm{kB}$ complexes.

\subsection{Overview of NF- $\kappa B$ and Cancer}

The first evidence for a role of NF- $\mathrm{KB}$ in cancer came from the characterization of the $\mathrm{v}$-rel oncogene of the avian Rev-T retrovirus [11]. Indeed, Rev-T is an extremely potent oncogenic agent and causes a rapidly lethal lymphoma when injected into young chickens. Moreover, substitution of the human REL proto-oncogene for v-rel in Rev-T is also highly oncogenic in chicken lymphoid cells, both in vivo and in vitro.

In spite of its potency as a single-agent oncogene in avian systems, NF- $\mathrm{kB}$ has not emerged as an efficacious mammalian oncogene in the manner of RAS, MYC, or SRC. Namely, no NF- $\mathrm{kB}$ protein has been shown to have rapid and strong oncogenic activity in any mammalian cell line or transgenic mouse model. Nevertheless, constitutively active canonical and noncanonical NF- $\mathrm{kB}$ has been found in over 40 cancer types (Table 1), and this activity has been implicated in a variety of standard cancer-associated biological processes, including cell survival, cell proliferation, metastasis, inflammation, angiogenesis, 
immune cell inhibition, growth factor activity, and stromal cell effects [12,13]. Relevant NF- $\mathrm{KB}$ target genes for many of these biological situations have been identified.

Table 1. Cancers that have been reported to have high NF- $\mathrm{B}$ activity.

\begin{tabular}{|c|c|}
\hline Hematological Malignancies & Solid Tumors \\
\hline Hodgkin lymphoma & Breast \\
\hline Acute lymphoblastic leukemia & Cervical \\
\hline Acute myelogenous leukemia & Ovarian \\
\hline Acute $\mathrm{T}$ cell leukemia & Vulvar \\
\hline Acute nonlymphocytic leukemia & Uterine (endometrial) \\
\hline Chronic lymphocytic leukemia & Prostate \\
\hline Chronic myelogenous leukemia & Testicular \\
\hline Burkitt lymphoma (EBV) & Penile \\
\hline Mantle cell lymphoma & Kidney \\
\hline Myelodysplastic syndrome & Bladder \\
\hline Multiple myeloma & Lung \\
\hline Diffuse large B cell lymphoma & Mesothelioma \\
\hline MALT lymphoma & Esophageal \\
\hline Mantle cell lymphoma & Laryngeal \\
\hline Marginal zone lymphoma & Liver \\
\hline \multirow[t]{15}{*}{ Waldenstrom's macroglobulinemia } & Pancreatic \\
\hline & Stomach \\
\hline & Colon \\
\hline & Thyroid \\
\hline & Parathyroid \\
\hline & Melanoma \\
\hline & Squamous cell carcinoma \\
\hline & Head and neck \\
\hline & Cylindromatosis \\
\hline & Trichoepithelioma \\
\hline & Hilar cholangiocarcinoma \\
\hline & Oral carcinoma \\
\hline & Tongue \\
\hline & Astrocytoma \\
\hline & GIST \\
\hline
\end{tabular}

For details, see http://www.bu.edu/nf-kb/physiological-mediators/diseases/.

\section{Cancer Cell-Induced Activation of NF-kB}

Unlike what is found in most normal cells, NF- $\mathrm{B}$ is constitutively located in the nucleus in many cancer cells. As discussed in this section, constitutive activation of NF- $\mathrm{kB}$ can occur by several mechanisms and in a large number of different cancers.

\subsection{Mutational Activation of NF- $\kappa B$ in Cancer}

NF- $\mathrm{kB}$ activity can be activated by cancer-associated gene mutation. These mutations can occur in both core NF-kB pathway proteins and upstream regulators of NF- $\mathrm{KB}$ (Table 2), and these mutations can affect either canonical or noncanonical NF- $\mathrm{kB}$ signaling. Such mutations are perhaps best characterized in hematological malignancies, including prominently B cell and $\mathrm{T}$ cell leukemias and lymphomas [14] and multiple myeloma [15]. Nevertheless, cancer genome sequencing projects are now uncovering NF- $\mathrm{kB}$ pathway mutations in many other cancer types.

The most highly studied malignancies with NF- $\mathrm{kB}$ mutations are diffuse large $\mathrm{B}$ cell lymphoma (DLBCL) [16] and multiple myeloma (MM) [17]. Indeed, mutation-based activation of canonical NF- $\mathrm{kB}$ defines a molecular subtype of DLBCL, which has a poorer clinical outcome in response to standard chemotherapy [16]. The canonical NF-kB-dependent subtype is called the activated $B$ cell (ABC) subtype, which was first defined by similarity to an mRNA expression profile of normal antigen-activated $B$ cells that have high expression of several direct NF- $\mathrm{kB}$ target genes [15]. Activating mutations of NF- $\mathrm{KB}$ occur in 
about $40 \%$ of DLBCLs and most commonly occur at multiple steps in the B cell receptor (BCR)-to-NF- $k B$ signaling pathway [18]. Frequent activation of the noncanonical NF- $\kappa B$ pathway has also been reported in all DLBCL subtypes [19] regardless of the canonical pathway status, indicating that noncanonical NF- $\mathrm{KB}$ signaling also represents a major driver of DLBCL. In DLBCL, some gain-of-function mutations generate chronic activators of NF- $\mathrm{KB}$ (e.g., mutations in CD79, MYD88, or REL gene amplification), whereas other loss-of-function mutations inactivate negative regulators of NF- $\mathrm{KB}$ (e.g., IKB, CYLD, A20, TRAF3) $[19,20]$. Similarly, multiple pathway activators can lead to constitutive canonical and noncanonical NF- $\mathrm{KB}$ pathway activation in MM in $20-40 \%$ of cases [15,21]. Moreover, NF- $\mathrm{kB}$ pathway inhibition can block the proliferation and survival of DLBCL and MM cell lines that have chronic activation of NF- $\mathrm{KB}$ in a variety of in vitro cell and in vivo mouse models $[15,16]$.

Nevertheless, it is important to note that mutation-based activation of NF- $\mathrm{KB}$ is simply one oncogenic driver pathway in most $\mathrm{B}$ cell malignancies. That is, there is a variety of other cooperating mutations in other cellular pathways, e.g., in proteins such as NOTCH, BCL6, IRF4, p300/CBP, that cluster with NF-KB pathway mutations to define further distinct genetic subtypes of DLBCL [18]. In some cases, these complementing alterations in signaling pathways may be required to keep NF- $\mathrm{KB}$ activity in the optimal range for the malignant process.

\subsubsection{Mutation of Core NF-kB Signaling Proteins}

NF- $\mathrm{KB}$ transcription factors are themselves targets for mutation in many cancers, although RELA and RELB are much less frequently mutated than REL, NFKB1, and NFKB2. Generally, oncogenic alterations in NF- $\mathrm{KB}$ proteins result in C-terminal truncations or single amino acid mutations, which lead to enhanced activity [22]. For example, Cterminal truncations that remove ANK repeat inhibitory sequences of p100 have been found in $\mathrm{B}$ and $\mathrm{T}$ cell lymphomas. C-terminal mutations that alter the transactivation activity have been characterized in REL and RELA [22]. REL gene amplifications, leading to increased REL protein expression, have been found in several types of lymphoma, including DLBCL and Hodgkin lymphoma [23,24].

Complete loss-of-function mutations have been found in IKB proteins, which lead to chronic nuclear localization of NF-kB in DLBCL [25], Hodgkin lymphoma [26], glioblastoma [27], and nasopharyngeal cancer [28]. Although much less frequent than mutations in NF-KB subunits or IKBs, constitutively activating mutations in IKK $\beta$ have been found in MM [29], mantle cell and marginal zone lymphomas [29], and prostate cancer [30], and IKK $\alpha$ mutations have been found in several cancer types [31]. The rarity of IKK mutations may be because IKK can function in a variety of signaling pathways in addition to NF-KB [32] and because overexpression of IKK is toxic in several cell systems.

\subsubsection{Mutation of Upstream Regulators of NF-KB in Lymphoma/Leukemia}

Probably the most common type of mutations for enhancing NF- $\mathrm{kB}$ signaling occurs in upstream or downstream molecules in specific pathways. In DLBCL and MM, this can include mutations in receptors (i.e., CD79 of the B cell receptor), adaptors (e.g., MYD88, CARMA1, BCL10) and pathway modulators (A20, CYLD, TRAFs, BTK, BIRC2/3) [15-19]. In short, DLBCL and MM are essentially genetic experiments that select for tumor cells that have mutations that drive sustained activation of canonical or noncanonical NF$\kappa B$, which is required for malignant $B$ cell proliferation and survival. Moreover, many DLBCLs or Hodgkin lymphomas have mutations in the transcriptional coactivators CBP, p300, and BCL3 [33], which are known to interact with NF-kB subunits on DNA to drive transcription. These coactivator mutations have been proposed to bring constitutive NF$\mathrm{kB}$-driven transcription to the optimal range for the given tumor [34]. Indeed, one human DLBCL cell line has been shown to have mutations that alter the activity of three NF- $\kappa B$ pathway proteins (REL, IkB, p300) [24,25]. 
Table 2. Some mutations in the NF-kB pathway in cancers.

\begin{tabular}{|c|c|c|c|c|c|}
\hline Gene & Protein & Type of Mutations & Effect on Activity & Cancer Type & Ref. \\
\hline \multicolumn{6}{|c|}{ Core NF- $\mathrm{kB}$ pathway proteins } \\
\hline NFKB1 & p50/p105 & Point mutations & Increase & $\mathrm{CC}, \mathrm{L}, \mathrm{G}, \mathrm{O}$ & {$[35,36]$} \\
\hline NFKB2 & $\mathrm{p} 52 / \mathrm{p} 100$ & C-terminal truncations & Increase & $\mathrm{B}$ and $\mathrm{T}$ cell $\mathrm{L} / \mathrm{Lym}$ & [22] \\
\hline RELA & RELA (p65) & Point mutations & Increase & MM & [37] \\
\hline$R E L$ & REL & $\begin{array}{l}\text { Amplifications } \\
\text { Point mutations } \\
\text { Truncations }\end{array}$ & $\begin{array}{l}\text { Increase } \\
\text { Increase } \\
\text { Decrease }\end{array}$ & $\begin{array}{l}\text { DLBCL } \\
\text { FL, DLBCL } \\
\text { DLBCL }\end{array}$ & [24] \\
\hline NFKBIA & $\mathrm{I} \kappa \mathrm{B} \alpha$ & Mutations/deletions & Decrease & DLBCL, GB, NPC & {$[22,27,28]$} \\
\hline NFIKBB & I $\mathrm{B} \beta$ & Point mutation & Decrease & MM & [38] \\
\hline NFKBIE & $\mathrm{I} \kappa \mathrm{B} \varepsilon$ & Deletions, point mutations & Decrease & CLL & {$[39]$} \\
\hline$B C L 3$ & BCL3 & Translocations & Increase & CLL & [40] \\
\hline CHUK & $\mathrm{IKK} \alpha$ & Point mutations & & & \\
\hline$I K B K B$ & $\mathrm{IKK} \beta$ & Point mutations & Increase & Pr, MM, Lym & {$[29,30]$} \\
\hline MAP3K14 & NIK & Gene fusion, point mutations & Increase & MM, HL & {$[38,41]$} \\
\hline \multicolumn{6}{|c|}{ Upstream modulators } \\
\hline$C D 79 A / B$ & CD79A/B & Point mutations & Increase & Lym & {$[14]$} \\
\hline MYD88 & MYD88 & Point mutations, deletions & Increase & Many & {$[18]$} \\
\hline BCL10 & BCL10 & $\begin{array}{c}\text { Point mutations, } \\
\text { chromosomal translocations }\end{array}$ & Increase & Lym & [42] \\
\hline MALT1 & MALT1 & $\begin{array}{c}\text { Chromosomal translocations, } \\
\text { point mutations, } \\
\text { amplifications }\end{array}$ & Increase & Lym & [43] \\
\hline TNFAIP3 & A20 & Point mutations & Decrease & Lym, NP & {$[28,44]$} \\
\hline CYLD & CYLD & Mutations, deletions & Decrease & Cyld, NP, MM & {$[45]$} \\
\hline TRAF1,4,5,6 & TRAF1,4,5,6 & $\begin{array}{l}\text { Amplifications, point } \\
\text { mutations, deletions }\end{array}$ & Increase & Many & [46] \\
\hline TRAF2,3 & TRAF2,3 & $\begin{array}{l}\text { Point mutation, deletion, } \\
\text { amplifcation }\end{array}$ & Decrease & Many & [46] \\
\hline CARMA1 & CARD11 & $\begin{array}{l}\text { Chromosomal translocation; } \\
\text { Point mutation }\end{array}$ & Increase & Leuk, Lym & [47] \\
\hline $\begin{array}{l}\text { HOIP, HOIL, } \\
\text { SHARPIN }\end{array}$ & LUBAC & Point mutations & Increase & DLBCL & [48] \\
\hline \multicolumn{6}{|c|}{ Coactivators } \\
\hline EP300 & p300 & Deletions & Decrease & DLBCL, Leuk, ST & {$[34,49]$} \\
\hline CREBBP & CBP & Deletions & Decrease & DLBCL, Leuk, ST & {$[34,49]$} \\
\hline
\end{tabular}

CC, cervical cancer; CLL, chronic lymphocytic leukemia; Cyld, cylindromatosis; DLBCL, diffuse large B cell lymphoma; G, gastric; GB, glioblastoma; HL, Hodgkin lymphoma; L, liver; Leuk, many leukemias; Lym, various B cell lymphomas; Many, many types of cancer; MM, multiple myeloma; NP, nasopharyngeal carcinoma; $\mathrm{O}$, ovarian; $\mathrm{Pr}$, prostate; ST, many solid tumors.

\subsection{Chronic Signal-Induced Activation of NF- $\kappa B$ in Some Cancers}

$\mathrm{NF}-\mathrm{KB}$ shows an oscillating pattern of activation/inactivation in the presence of a continous activating signal due to the negative feedback in NF- $\kappa B$ signaling provided by new synthesis of IkB [50]. In many tumor settings, constitutive activation of NF- $\mathrm{kB}$ can also be achieved by autocrine, often stromal, activation of NF-kB (e.g., by cytokines [51] or other stimulus-dependent activations of the pathway). For example, TNF is encoded by a direct $\mathrm{NF}-\mathrm{kB}$ target gene that can function as a chronic activator of NF- $\mathrm{KB}$ in an autocrine manner for certain tumor cells with constitutive activation of NF- $\mathrm{kB}$ [52]. Furthermore, some 
DLBCLs become dependent on TLR-based activation of NF- $\mathrm{B}$ by specific antigens [18]. In other cases, chronic stimulation of the TLR pathway by pathogens has been associated with cancer. For example, Muto et al. [53] showed that TRAF6 overexpression resulting from somatic alterations in preleukemic myelodysplastic hematopoietic stem cells (MDS HSCs) causes a switch from canonical to noncanonical NF- $\mathrm{KB}$ signaling during inflammation; this switch to noncanonical signaling provides these MDS HSCs with a competitive growth and survival advantage over noninflamed normal HSCs.

\subsection{Epigenetic and Genomic Effects Involving NF- $\kappa B$ in Cancer}

A variety of studies have shown that chromatin state can influence the binding of NF- $\kappa B$ to various promoters $[3,54]$. That is, induced NF- $\kappa B$ binds preferentially to genomic sites that are epigenetically primed. In addition, NF- $\kappa \mathrm{B}$ can recruit chromatinmodifying coactivators (e.g., histone acetyltransferases and histone deacetylases) to further modify local chromatin. Given the broad role of epigenetic changes in cancer [55], it is not surprising that there can also be interplay between epigenetic DNA status or epigenetic regulators and the chronically active NF- $\mathrm{kB}$ that is found in many cancers. For example, the gene encoding the epigenetic regulator protein MLL is changed by chromosomal alterations that generate oncogenic MLL fusion proteins that drive many leukemias, and the activity of these leukemogenic MLL fusion proteins requires NF- $\kappa B$ [56]. On the other hand, epigenetic methylation at the promoter of the FAS death receptor in certain cancers reduces NF- $\mathrm{BB}$-dependent activation of FAS expression, thus contributing to tumor cell survival by reducing levels of the proapoptotic FAS protein [57].

Similarly, it is now clear that mutations in noncoding sequences can also contribute to cancer by affecting transcription and gene expression [58]. Mutations in promoter sequences that affect NFKB1 expression or NF-KB-dependent expression of target genes have been described in oral, bladder, and breast cancer [59-61]. Furthermore, aberrant alternative splicing of the NF- $\kappa B$ inhibitor CYLD may lead to chronic activaiton of NF- $\mathrm{B}$ in some cases of chronic lymphocytic leukemia [62].

\subsection{Oncogenic Human Viruses That Affect NF-אB Signaling}

Several human viruses have been associated with cancer, and many of these viruses use cellular signaling pathways, including NF- $\mathrm{B}$, for their replication and pathogenesis [63]. Often, these viruses are oncogenic when their replication is aborted or chronic. Thus, these viruses can contribute to the oncogenic state either through chronic NF- $\mathrm{BB}-$ dependent inflammation or by the sustained activity of viral activators of NF-kB. Examples of virally encoded NF- $\mathrm{kB}$ activators include the LMP1 protein of Epstein-Barr virus (B cell lymphoma, nasopharyngeal carcinoma) [64], the vFLIP protein of Kaposi sarcoma herpesvirus (sarcoma, lymphoma) [64], the Tax protein of HTLV-1 (T cell leukemia) [65], the X protein of hepatitis $B$ virus (liver cancer) [66], and the E6 and E7 proteins of some strains of the human papillomavirus (cervical cancer) [67].

\section{Cancer-Related Processes Affected by Chronic Activation of NF- $k B$}

\subsection{Cell Survival}

One of the many cancer-promoting cellular processes affected by NF- $\kappa \mathrm{B}$ is cell survival, where NF- $k B$ generally acts by blocking apoptosis [68]. The first experiments demonstrating a role for NF- $\mathrm{kB}$ in cell survival were ones showing that inactivation of the v-rel oncogene caused transformed lymphoid cells to die of apoptosis [69] and that knockout of the rela gene caused mouse fibroblasts and embryonic liver cells to undergo apoptosis in response to the tumor necrosis factor $[70,71]$. Thus, in a variety of tumor cells with constitutive NF- $\kappa B$ activity, one finds upregulation of direct NF- $\kappa B$ target genes that encode antiapoptotic molecules such as BCL2, BCLXL, and IAPs. In particular, NF-kB's ability to block apoptosis is important for $\mathrm{B}$ and $\mathrm{T}$ cell malignancies where their normal endpoint of proliferation cycles is apoptosis [16] and in the resistance of tumor cells to chemotherapeutic agents and radiation [72]. 
In some cancer-related situations, however, NF- $\mathrm{kB}$ is required for apoptosis. In most of these cases, NF- $\kappa \mathrm{B}$ is required for efficient drug-induced apoptosis in various cancer cell lines. For example, inhibition of NF- $\mathrm{KB}$ reduces apoptosis induced by doxorubicin in neuroblastoma cells [73], by etoposide in HL-60 myeloid leukemia cells [74], and by UV irradiation in melanoma cells [75]. In some of these cases, NF- $\kappa$ B may be a cell type-specific repressor of the antiapoptotic genes discussed above or an activator of proapoptotic genes such as BAX [76], BIM [77], CASPASE-11 [78], and FAS [79].

\subsection{Cell Proliferation}

Several NF- $\mathrm{kB}$ target genes that contribute to cell proliferation have been identified. Such direct pro-proliferation targets include several cell cycle genes [80], including notably cyclin D1 [81], and the CD44 gene required for breast cancer cell proliferation [82]. Furthermore, in several settings, NF-KB has been shown to be a required downstream pathway for RAS-induced transformation $[83,84]$. It is not always clear whether the pro-proliferative dysregulation of NF- $\mathrm{KB}$ is directly involved in changes in expression of proliferation genes or it is due to a change in the apoptotic or epigenetic state of the tumor cell.

\subsection{Inflammation}

NF- $\kappa$ B plays a prominent role in innate immunity in both normal inflammation and dysregulated chronic disease-promoting inflammation that is associated with autoimmune diseases, tissue damage, and many types of cancer [85]. Chronic inflammation contributes to cancer by increasing cellular stress responses, recruiting inflammatory factors, and can also change the epigenetic state of many genes. As such, many cytokine genes (e.g., TNF $\alpha$, IL-1, IL-6, IL-17) are direct targets of NF- $\mathrm{kB}$ and are known to be protumorigenic, especially as related to stomach/bowel cancers (e.g., inflammatory bowel disease) $[86,87]$ and stromal contributions in MM [16]. Intriguingly, one recent large-scale study [4] showed that many cancers have an inflammatory gene network that involves interactions of the transcription factors STAT3, NF- $\mathrm{B}$, and AP-1 at common DNA sites where NF- $\mathrm{B}$, in many cases, is only indirectly associated with DNA by virtue of its interaction with STAT3 or AP-1 on DNA.

\subsection{Other Hallmarks of Cancer: Angiogenesis, Metastasis, and Cell Immortalization}

In addition to the direct effects of inflammatory molecules on cancer cell properties such as proliferation, survival, and inflammation, cancer-activated NF- $\mathrm{kB}$ can promote tumor-associated processes such as angiogenesis [88], epithelial mesenchymal transition (EMT) (e.g., matrix metalloproteinase-3 (MMP3) expression [89]), and metastasis (e.g., MMP9 regulation [90]).

Several proangiogenic molecules, including VEGF (vascular endothelial growth factor), IL-8, and MMP9, have been shown to be downregulated in prostate cancer and hemangioma tumor cells [91], and inhibition of NF- $\mathrm{B}$ in these cells blocked their ability to promote angiogenesis. Furthermore, NF- $\mathrm{BB}$ has been shown to be important for blood vessel endothelial cell survival in response to TNF [92], which is present at high levels in many inflamed cancers. Several of the same types of molecules that play a role in angiogenesis also promote EMT and metastasis. Thus, it is not surprising that NF- $\mathrm{B}$ has also been shown to have a role in some metastasis models, including pancreatic cancer [93]. Moreover, some of the primary EMT molecules, including TWIST, SLUG, and SIP1, have been shown to be regulated by NF-KB [94].

NF- $\mathrm{BB}$ has also been implicated in cellular immortalization. For example, NF- $\mathrm{B}$ has been shown to have a complex interaction with the catalytic subunit of telomerase (hTERT): that is, the hTERT gene has been reported to be a direct target for NF-kB [95] and the hTERT protein has been shown to interact directly with RELA to affect RELA's nuclear translocation and transcriptional activation activity [89]. Similarly, NF- $\kappa$ B has been reported to induce the bypass of senescence in melanoma cells [96]. 


\subsection{Immunosuppression}

In the past decade, it has become clear that many tumors create an immunosuppressed environment that is required for their progression. In some cases, this immunosuppression involves the recruitment of immune cells such as regulatory T cells (Tregs) or M2-biased tumor-infiltrating macrophages (TAMs) to the tumor. NF- $\mathrm{kB}$ has been shown to be involved in these processes in several ways. First, c-rel is required for the development of Tregs [97]. Second, increased NF-kB p50 activity is associated with an M1- to M2-polarized (protumorigenic and immunosuppressive) state in macrophages $[98,99]$. In addition, the gene encoding the checkpoint inhibitor protein PD-L1 is an NF- $\mathrm{KB}$ target gene [100], suggesting that inflammation can promote a $\mathrm{T}$ cell-based immunosuppressive environment that contributes to the survival of some tumors.

Thus, NF-kB can contribute directly to tumor cell proliferation and survival, as well as to biological processes that affect the malignant state and progression of the tumor. Cancer-related biological processes regulated by NF- $\mathrm{kB}$ and some of the NF- $\mathrm{KB}$ target genes involved in these processes are listed in Table 3.

Table 3. Some cancer-relevant biological processes and relevant target genes controlled by NF- $\mathrm{kB}$.

\begin{tabular}{ccc}
\hline Biological Process & Relevant Target Genes & Ref. \\
\hline Cell survival (antiapoptosis) & BCL2, BCLXL, IAPs & {$[68]$} \\
Cell cycle & CCND1, CD44, CDK2, CDKN1A & {$[80]$} \\
Metastasis & MMP2, MMP9, UPA, SOX9 & {$[101]$} \\
Angiogenesis & IL-1 $\beta$, IL-8, MMP9, VEGF-A, FASL & {$[102]$} \\
Epithelial-to-mesenchymal transition & TWIST1, SLUG, SIP1, SNAIL & {$[94,103]$} \\
Inflammation & CXCL8, IL-6, TNFA, IL-1 $\beta$, iNOS, COX2 & {$[85]$} \\
Immortalization & TERT, EZH2 & {$[104]$} \\
Senescence & IL-6, TNFA, IL-1 $\beta$ & {$[105]$} \\
Energy metabolism & GLUT3, SCO2 & {$[106]$} \\
T cell inhibition & FOXP3, PDCD1 & {$[107]$} \\
Cancer stem cells & NANOG, SOX2, CD44, KLF4 & {$[101]$} \\
\hline
\end{tabular}

\section{NF- $\kappa$ B as a Tumor Suppressor}

In a limited number of cases, NF- $\mathrm{kB}$ has been reported to have tumor suppressor activity. However, this activity has generally been demonstrated in mouse or cell-based models. For example, downregulation of NF- $\kappa B$ by transgenic overexpression of IкB $\alpha$ led to skin epidermal hyperplasia in mice [108], and some RelA knockout mouse cell lines have a weakly transformed phenotype [109]. However, in both of those cases, the direct oncogenic effect of reduced NF- $\mathrm{KB}$ activity is not clear. Moreover, tumor suppressor activity of NF- $\mathrm{KB}$ has not been well-documented in human cancers [110]. Nevertheless, the extensive crosstalk between NF- $\mathrm{kB}$ and both wild-type and mutant tumor suppressor p53 indicates that NF- $\mathrm{kB}$ may play a role in tumor suppression in humans in certain circumstances [111].

\section{Targeting of NF- $k B$ for Cancer Therapy}

Based on the pervasive involvement of NF- $\mathrm{KB}$ in oncogenesis, it is not surprising that NF- $\mathrm{kB}$ signaling would be considered as a target for human cancer therapy. Indeed, there are well over 1000 inhibitors that can block NF- $\mathrm{KB}$ signaling [112], and inhibition of NF- $\mathrm{KB}$ can block cancer cell proliferation or survival in a number of animal models. Nevertheless, inhibitors of NF- $\mathrm{kB}$ signaling have not had a dramatic impact on general cancer therapy, in part because of the liver toxicity of many NF- $\mathrm{kB}$ inhibitors and the rapid development of parallel pathway resistance. Still, proteasome inhibitors (which block IkB degradation for canonical and noncanonical signaling) have been quite effective for the treatment of multiple myeloma [15], and they appear to act, at least in part, due to their inhibitory effects on NF-kB signaling. Similarly, Bruton's tyrosine kinase (BTK) inhibitors have been useful in the treatment of NF-kB-positive DLBCL [113] as BTK is required for the BCR-NF- $\mathrm{kB}$ 
pathway in B cells. Finally, whether inhibition of NF- $\mathrm{B}$ might promote cancer in some cases by affecting tumor-suppressing activity of NF- $\mathrm{KB}$ or by having a detrimental effect on patient antitumor $\mathrm{T}$ cell immunity (natural or induced by immunotherapy) is not clear.

\section{Future Considerations}

It is likely that NF- $\mathrm{BB}$ will be found to be associated with many more cancers, especially as we accumulate additional whole genome sequence data. Nevertheless, it is unlikely that sustained, systemic, and complete inhibition of upstream NF- $\kappa$ B pathways will be a useful primary strategy for cancer or any other disease. That being said, agents and doses that reduce (but do not eliminate) cancer-induced NF- $\kappa$ B activity or inflammation may well be useful. Moreover, it has been generally difficult to directly target the NF- $\mathrm{B}$ transcription factors themselves [114], which may be a more proximal and reduced offtarget strategy given, for example, the viability of c-rel knockout mice [24]. Still, acute and strong inhibition of NF- $\mathrm{KB}$ as adjuvant therapy may be useful in certain cancer regimens. Alternatively, therapies that can distinguish and target oncogenic NF- $\mathrm{kB}$ activity versus normal NF- $\mathrm{KB}$ activity are required. Indeed, direct inhibitors of oncogenic RAS have only recently started being used in the clinic for cancer therapy [115], forty years after the discovery of RAS, demonstrating the difficulty of developing useful cancer therapeutics in pervasive and important signaling pathways. Intriguingly, NF- $\mathrm{B}$ has been shown to be required for downstream RAS signaling in some cancers [81,82]. Thus, it is almost certain that research on pathological NF- $\kappa$ B activity will continue to occupy an important place in cancer research, and modern genome modification methods and/or new therapeutic strategies to target NF-кB activity will prove useful in certain settings.

Funding: The author's research on the role of NF- $\mathrm{kB}$ in human disease has most recently been supported by NIH grant GM117350.

Acknowledgments: The author thanks Véronique Baud for comments on the manuscript. In many cases, the author has cited reviews of given topics, and thus he apologizes for the many primary citations that were not included in this general overview of cancer-related processes regulated by NF-kB.

Conflicts of Interest: The author declares no conflict of interest.

\section{References}

1. Zhang, Q.; Lenardo, M.J.; Baltimore, D. 30 years of NF-kB: A blossoming of relevance to human pathobiology. Cell 2017, 168, 37-57. [CrossRef]

2. Gilmore, T.D. Introduction to NF-кB: Pathways, players, perspectives. Oncogene 2006, 25, 6684-6690. [CrossRef] [PubMed]

3. Mulero, C.M.; Wang, V.Y.-F.; Huxford, T.; Ghosh, G. Genome reading by the NF-kB transcription factors. Nucleic Acids Res. 2019, 47, 9967-9989. [CrossRef] [PubMed]

4. Ji, Z.; He, L.; Regev, A.; Struhl, K. Inflammatory regulatory network mediated by the joint action of NF-kB, STAT3, and AP-1 factors is involved in many human cancers. Proc. Natl. Acad. Sci. USA 2019, 116, 9453-9462. [CrossRef] [PubMed]

5. Hayden, M.S.; Ghosh, S. Shared principles of NF-кB signaling. Cell 2008, 132, 344-362. [CrossRef] [PubMed]

6. Sun, S.-C. The noncanonical NF-kB pathway. Immunol. Rev. 2012, 246, 125-140. [CrossRef]

7. Shi, J.H.; Sun, S.-C. Tumor necrosis factor receptor-associated factor regulation of nuclear factor $\mathrm{kB}$ and mitogen-activated protein kinase pathways. Front. Immunol. 2018, 9, 1849. [CrossRef]

8. Kawai, T.; Akira, S. Signaling to NF-кB by Toll-like receptors. Trends Mol. Med. 2007, 13, 460-469. [CrossRef]

9. Tan, X.; Sun, L.; Chen, J.; Chen, Z.J. Detection of microbial infections through innate immune sensing of nucleic acids. Annu. Rev. Microbiol. 2018, 72, 447-478. [CrossRef]

10. Kawasaki, T.; Kawai, T. Toll-like receptor signaling pathways. Front. Immunol. 2014, 5, 461. [CrossRef]

11. Gilmore, T.D. Multiple mutations contribute to the oncogenicity of the retroviral oncoprotein, v-Rel. Oncogene 1999, $18,6925-6937$. [CrossRef] [PubMed]

12. Xia, Y.; Shen, S.; Verma, I.M. NF-kB, an active player in human cancers. Cancer Immunol. Res. 2014, 2, 823-830. [CrossRef] [PubMed]

13. Tegowski, M.; Baldwin, A. Noncanoncial NF-kB in cancer. Biomedicines 2018, 6, 66. [CrossRef]

14. Lim, K.-H.; Yang, Y.; Staudt, L.M. Pathogenetic importance and therapeutic implications of NF- $\mathrm{kB}$ in lymphoid malignancies. Immunol. Rev. 2012, 246, 359-378. [CrossRef] [PubMed] 
15. Vrábel, D.; Pour, L.; Ševčková, S. The impact of NF-kB signaling on pathogenesis and current treatment strategies in multiple myeloma. Blood Rev. 2019, 34, 56-66. [CrossRef]

16. Staudt, L.M. Oncogenic activation of NF-кB. Cold Spring Harb. Perspect. Biol. 2010, 2, a000109. [CrossRef]

17. Matthews, G.M.; de Matos Simoes, R.; Dhimolea, E.; Sheffer, M.; Gandolfi, S.; Dashevsky, O.; Sorrell, J.D.; Mitsiades, C.S. NF-кB dysregulation in multiple myeloma. Semin. Cancer Biol. 2016, 39, 68-76. [CrossRef]

18. Young, R.M.; Phelan, J.D.; Wilson, W.H.; Staudt, L.M. Pathogenic B-cell receptor signaling in lymphoid malignancies: New insights to improve treatment. Immunol. Rev. 2019, 291, 190-213. [CrossRef]

19. Eluard, B.; Nuan-Aliman, S.; Collares, F.N.; Bordereaux, D.; Montagne, A.; Martins, I.; Cagnard, N.; Caly, M.; Taoui, O.; Lordello, L.; et al. The alternative ReB NF-kB subunit is a novel critical player in diffuse large B-cell lymphoma. Blood 2021, in press. [CrossRef]

20. Schmitz, R.; Wright, G.W.; Huang, D.W.; Johnson, C.A.; Phelan, J.D.; Wang, J.Q.; Roulland, S.; Kasbekar, M.; Young, R.M.; Shaffer, A.L.; et al. Genetics and pathogenesis of diffuse large B-cell lymphoma. N. Engl. J. Med. 2018, 378, 1396-1407. [CrossRef]

21. Roy, P.; Aditya Sarkar, U.; Basak, S. The NF-кB activating pathways in multiple myeloma. Biomedicines 2018, 6, 59. [CrossRef]

22. Courtois, G.; Gilmore, T.D. Mutations in the NF-kB signaling pathway: Implications for human disease. Oncogene 2006, 25, 6831-6843. [CrossRef]

23. Weniger, M.A.; Küppers, R. Molecular biology of Hodgkin lymphoma. Leukemia 2021, 35, 968-981. [CrossRef]

24. Gilmore, T.D.; Gerondakis, S. The c-Rel transcription factor in development and disease. Genes Cancer 2011, 2, 695-711. [CrossRef] [PubMed]

25. Kalaitzidis, D.; Davis, R.E.; Rosenwald, A.; Staudt, L.M.; Gilmore, T.D. The human B-cell lymphoma cell line RC-K8 has multiple genetic alterations that dysregulate the Rel/NF-B signal transduction pathway. Oncogene 2002, 21, 8759-8768. [CrossRef] [PubMed]

26. Lake, A.; Shield, L.A.; Cordono, P.; Chui, D.T.Y.; Osborne, J.; Crae, S.; Wilson, K.S.; Tosi, S.; Knight, S.J.L.; Gesk, S.; et al. Mutations of NFKBIA, encoding IkBa, are a recurrent finding in classical Hodgkin lymphoma but are not a unifying feature of non-EBV-associated cases. Int. J. Cancer 2009, 125, 1334-1342. [CrossRef]

27. Bredel, M.; Scholtens, D.M.; Yadav, A.K.; Alvarez, A.A.; Renfrow, J.J.; Chandler, J.P.; Yu, I.L.Y.; Carro, M.S.; Dai, F.; Tagge, M.J.; et al. NFKBIA deletion in glioblastomas. N. Engl. J. Med. 2011, 364, 627-637. [CrossRef]

28. Zheng, H.; Dai, W.; Cheung, A.K.L.; Koa, J.M.Y.; Kan, R.; Wong, B.W.Y.; Leong, M.M.L.; Deng, M.; Kwok, T.C.T.; Chan, J.Y.-W.; et al. Whole-exome sequencing identifies multiple loss-of-function mutations of NF- $\kappa \mathrm{B}$ pathway regulators in nasopharyngeal carcinoma. Proc. Natl. Acad. Sci. USA 2016, 113, 11283-11288. [CrossRef] [PubMed]

29. Meyer, A.N.; Gallo, L.H.; Ko, J.; Cardenas, G.; Nelson, K.N.; Siari, A.; Campos, A.R.; Whisenant, T.C.; Donoghur, D.J. Oncogenic mutations in IKK $\beta$ function through global changes induced by K63-linked ubiquitination and result in autocrine stimulation. PLoS ONE 2018, 13, e0206014. [CrossRef] [PubMed]

30. Pflueger, D.; Terry, S.; Sboner, A.; Habegger, L.; Exgueva, R.; Lin, P.-C.; Svensoon, M.A.; Kitabayashi, N.; Moss, B.J.; MacDonald, T.Y.; et al. Discovery of non-ETS gene fusions in human prostate cancer using next-generation RNA sequencing. Genome Res. 2011, 21, 56-67. [CrossRef]

31. Greenman, C.; Stephens, P.; Smith, R.; Dalgliesh, G.L.; Hunter, C.; Bignell, G.; Davies, H.; Teague, J.; Butler, A.; Stevens, C.; et al. Patterns of somatic mutation in human cancer genomes. Nature 2007, 446, 153-158. [CrossRef]

32. Antonia, R.J.; Hagan, R.S.; Baldwin, A.S. Expanding the view of IKK: New substrates and new biology. Trends Cell Biol. 2021, 31, 166-178. [CrossRef]

33. Shaknovich, R.; Melnick, A. Epigenetics and B-cell lymphoma. Curr. Opin. Hematol. 2011, 18, 293-299. [CrossRef] [PubMed]

34. Haery, L.; Thompson, R.C.; Gilmore, T.D. Histone acetyltransferase and histone deacetylases in B- and T-cell development, physiology and malignancy. Genes Cancer 2015, 6, 184-213. [CrossRef]

35. Concetti, J.; Wilson, C.L. NFKB1 and cancer: Friend or foe? Cells 2018, 7, 133. [CrossRef] [PubMed]

36. Yang, D.; Zhang, W.; Liang, J.; Ma, K.; Chen, P.; Lu, D.; Hao, W. Single cell whole genome sequencing reveals that NFKB1 mutation affects radiotherapy sensitivity in cervical cancer. Oncotarget 2018, 9, 7332-7340. [CrossRef] [PubMed]

37. Trecca, D.; Guerrini, L.; Fracchiolla, N.S.; Pomati, M.; Baldini, L.; Maiolo, A.T.; Neri, A. Identification of a tumor-associated mutant form of the NF-кB RelA gene with reduced DNA-binding and transactivating activities. Oncogene 1997, 14, 791-797.

38. Chapman, M.A.; Lawrence, M.S.; Keats, J.J.; Cibulskis, K.; Sougnez, C.; Harview, C.L.; Brunet, J.P.; Ahmann, G.J.; Adli, M.; Anderson, K.C.; et al. Initial genome sequencing and analysis of multiple myeloma. Nature 2011, 471, 467-472. [CrossRef]

39. Mansouri, L.; Papakonstantinou, N.; Ntoufa, S.; Stamatopoulos, K.; Rosenquist, R. NF-kB activation in chronic lymphocytic leukemia: A point of convergence of external triggers and intrinsic lesions. Semin. Cancer Biol. 2016, 39, 40-48. [CrossRef]

40. Lenardo, M.; Siebenlist, U. Bcl-3-mediated nuclear regulation of the NF-kB trans-activating factor. Immunol. Today 1994, 15, 145-147. [CrossRef]

41. Maubach, G.; Feige, M.H.; Lim, M.C.C.; Naumann, M. NF-kB-inducing kinase in cancer. Biochim. Biophys. Acta Rev. Cancer 2019, 1871, 40-49. [CrossRef] [PubMed]

42. Gehring, T.; Seeholzer, T.; Krappmann, D. BCL10-Bridging CARDs to immune activation. Front. Immunol. 2018, 9, 1539. [CrossRef] [PubMed]

43. Ruland, J.; Hartjes, L. CARD-BCL-10-MALT1 signalling in protective and pathological immunity. Nat. Rev. Immunol. 2019, 19, 118-134. [CrossRef] 
44. Ma, A.; Malynn, B.A. A20: Linking a complex regulator of ubiquitylation to immunity and human disease. Nat. Rev. Immunol. 2012, 12, 774-785. [CrossRef]

45. Massoumi, R. CYLD: A deubiquitination enzyme with multiple roles in cancer. Fut. Oncol. 2011, 7, 285-297. [CrossRef]

46. Zhu, S.; Jin, J.; Gokhale, S.; Lu, A.M.; Shan, H.; Feng, J.; Xie, P. Genetic alterations of TRAF proteins in human cancers. Front. Immunol. 2018, 9, 2111. [CrossRef]

47. Juilland, M.; Thome, M. Role of the CARMA1/BCL10/MALT1 complex in lymphoid malignances. Curr. Opin. Hematol. 2016, 23, 402-409. [CrossRef] [PubMed]

48. Yang, Y.; Staudt, L.M. Protein ubiquitination in lymphoid malignancies. Immunol. Rev. 2015, 263, 240-256. [CrossRef] [PubMed]

49. Iyer, N.G.; Özdag, H.; Caldas, C. p300/CBP and cancer. Oncogene 2004, 23, 4225-4231. [CrossRef]

50. Basak, S.; Behar, M.; Hoffmann, A. Lessons from mathematically modeling the NF-kB system. Immunol. Rev. 2012, 246, 221-238. [CrossRef] [PubMed]

51. Ben-Neriah, Y.; Karin, M. Inflammation meets cancer, with NF-kB as the matchmaker. Nat. Immunol. 2011, 12, 715-723. [CrossRef]

52. Balkwill, F. Tumor necrosis factor and cancer. Nat. Rev. Cancer 2009, 9, 361-371. [CrossRef]

53. Muto, T.; Walker, C.S.; Choi, K.; Hueneman, K.; Smith, M.A.; Gul, Z.; Garcia-Manero, G.; Ma, A.; Zheng, Y.; Starczynowski, D.T. Adaptive response to inflammation contributes to sustained myelopoiesis and confers a competitive advantage in myelodysplastic syndrome HSCs. Nat. Immunol. 2020, 21, 535. [CrossRef]

54. Bhatt, D.; Ghosh, S. Regulation of the NF-кB-mediated transcription of inflammatory genes. Front. Immunol. 2014, 5, 71. [CrossRef] [PubMed]

55. Dawson, M.A.; Kouzarides, T. Cancer epigenetics: From mechanism to therapy. Cell 2012, 150, 12-27. [CrossRef]

56. Kuo, H.-P.; Wang, Z.; Lee, D.-F.; Iwasaki, M.; Duque-Afonxo, J.; Wong, S.H.K.; Lin, C.-H.; Figueroa, M.E.; Su, J.; Lemischka, I.R.; et al. Epigenetic roles of MLL oncoproteins are dependent on NF-кB. Cancer Cell 2013, 24, 423-437. [CrossRef]

57. Ettou, S.; Humbrecht, C.; Benet, B.; Billot, K.; d'Allard, D.; Mariot, V.; Goodhardgt, M.; Kosmider, O.; Mayeux, P.; Solary, E.; et al. Epigenetic control of NF- $\mathrm{KB}-$ dependent FAS gene transcription during progression of myelodysplastic syndromes. Mol. Cancer Res. 2013, 11, 724-735. [CrossRef] [PubMed]

58. Patel, M.B.; Wang, J. The identification and interpretations of cis-regulatory noncoding mutations in cancer. High. Throughput 2018, 8, 1. [CrossRef] [PubMed]

59. Lin, S.-C.; Liu, C.-J.; Yeh, W.-I.; Lui, M.-T.; Chang, K.-W.; Chang, C.-S. Functional polymorphism in NFKB1 promoter is related to the risks of oral squamous cell carcinoma occurring on older male areca (betel) chewers. Cancer Lett. 2006, 243, 47-54. [CrossRef]

60. Saha, A.; Bairwa, N.K.; Ranjan, A.; Gupta, V.; Bamezai, R. Two novel somatic mutations in the human interleukin 6 promoter region in a patient with sporadic breast cancer. Eur. J. Immunogenet. 2003, 30, 397-400. [CrossRef]

61. Kang, S.; Kim, Y.B.; Kim, M.H.; Yoon, K.S.; Kim, J.W.; Park, N.H.; Song, Y.S.; Kang, D.; Yoo, K.Y.; Kang, S.B.; et al. Polymorphism in the nuclear factor kappa-B binding promoter region of cyclooxygenase-2 is associated with increased risk of bladder cancer. Cancer Lett. 2005, 217, 11-16. [CrossRef]

62. Hahn, M.; Bürckert, J.-P.; Luttenberger, C.A.; Klebow, S.; Hess, M.; Al-Maarri, M.; Vogt, M.; Reißig, S.; Hallek, M.; WieneckeBaldacchino, A.; et al. Aberrant splicing of the tumor suppressor CYLD promotes the development of chronic lymphocytic leukemia via sustained NF-kB signaling. Leukemia 2018, 32, 72-82. [CrossRef] [PubMed]

63. Gilmore, T.D.; Mosialos, G. Viruses as intruders in the Rel/NF-kB signaling pathway. In Nuclear Factor-kB: Regulation and Role in Disease; Beyaert, R., Ed.; Kluwer Academic Publishers: Amsterdam, The Netherlands, 2003; pp. 91-115.

64. Charostad, J.; Nakhaie, M.; Dehghani, A.; Faghihloo, E. The interplay between EBV and KSHV viral products and NF-kB pathway in oncogenesis. Infect. Agent Cancer 2020, 15, 62. [CrossRef] [PubMed]

65. Harhaj, E.W.; Giam, C.-Z. NF-кB signaling mechanisms in HTLV-1-induced adult T-cell leukemia/lymphoma. FEBS J. 2018, 285, 3324-3336. [CrossRef]

66. Shokri, S.; Mahmoudvand, S.; Taherkhani, R.; Farshadpour, F.; Jalalian, F.A. Complexity on modulation of NF- $\mathrm{kB}$ pathways by hepatitis B and C: A double-edged sword in hepatocarcinogenesis. J. Cell. Physiol. 2019, 234, 14734-14742. [CrossRef]

67. Costa, D.A.; Bastos, R.M.; Medeiros, R.; Oliveira, P.A. The NFkB signaling pathway in papillomavirus-induced lesions: Friend or foe? Anticancer Res. 2016, 36, 2073-2083.

68. Barkett, M.; Gilmore, T.D. Control of apoptosis by Rel/NF-kB transcription factors. Oncogene 1999, 18, 6910-6924. [CrossRef]

69. White, D.W.; Roy, A.; Gilmore, T.D. The v-Rel oncoprotein blocks apoptosis and proteolysis of IкB- $\alpha$ in transformed chicken spleen cells. Oncogene 1995, 10, 857-868. [PubMed]

70. Beg, A.A.; Baltimore, D. An essential role for NF- $\mathrm{BB}$ in preventing TNF- $\alpha$-induced cell death. Science 1996, 274, 782-784. [CrossRef] [PubMed]

71. Beg, A.A.; Sha, W.C.; Bronson, R.T.; Ghosh, S.; Baltimore, D. Embryonic lethality and liver degeneration in mice lacking the RelA component of NF-kB. Nature 1995, 376, 167-170. [CrossRef]

72. Li, F.; Sethi, G. Targeting transcription factor NF- $\mathrm{KB}$ to overcome chemoresistance and radioresistance in cancer therapy. Biochim. Biophys. Acta 2010, 1805, 167-180. [CrossRef] [PubMed]

73. Bian, X.; McAllister-Lucas, L.M.; Shao, F.; Schumacher, K.R.; Feng, Z.; Porter, A.G.; Castle, V.P.; Opipari, A.W., Jr. NF-kB activation mediates doxorubicin-induced cell death in N-type neuroblastoma cells. J. Biol. Chem. 2001, 276, 48921-48929. [PubMed] 
74. Bessho, R.; Matsubara, K.; Kuboto, M.; Kuwakado, K.; Hirota, H.; Wakazono, Y.; Lin, Y.W.; Okuda, A.; Kawai, M.; Nishikomori, R.; et al. Pyrrolidine dithiocarbamate, a potent inhibitor of nuclear factor $\mathrm{\kappa B}(\mathrm{NF}-\mathrm{\kappa B})$ activation, prevents apoptosis in human promyelocytic leukemia HL-60 cells and thymocytes. Biochem. Pharmacol. 1994, 48, 1883-1889. [CrossRef]

75. Ivanov, V.N.; Ronai, Z. p38 protects human melanoma cells from UV-induced apoptosis through down-regulation of NF- $\mathrm{kB}$ activity and Fas expression. Oncogene 2000, 19, 3003-3012. [CrossRef]

76. Grimm, T.; Schneider, S.; Naschberger, E.; Huber, J.; Guenzi, E.; Kieser, A.; Reitmeir, P.; Schulz, T.F.; Morris, C.A.; Stürzl, M. EBV latent membrane protein-1 protects B cells from apotosis by inhibition of BAX. Blood 2005, 105, 3263-3269. [CrossRef] [PubMed]

77. Wang, Z.; Zhang, B.; Yang, L.; Ding, J.; Ding, H.-F. Constitutive production of NF-kappaB2 p52 is not tumorigenic by predisposes mice to inflammatory autoimmune disease by repressing Bim expression. J. Biol. Chem. 2008, 283, 10698-10706. [CrossRef]

78. Schauvliege, R.; Vanrobaeys, J.; Schotte, P.; Beyaert, R. Caspase-11 gene expression in response to lipopolysaccharide and interfereon- $\gamma$ required nuclear factor- $\mathrm{kB}$ and signal transducer and activator of transcription (STAT) 1. J. Biol. Chem. 2002, 277, 624-630. [CrossRef]

79. Singh, N.P.; Nagarkatti, M.; Nagarkatti, P.S. Role of dioxin response element and nuclear factor- $\kappa$ B motifs in 2,3,7,8tetrachlorodibenzo- $p$-dioxin-mediated regulation of Fas and Fas ligand expression. Mol. Pharmacol. 2007, 71, 145-157. [CrossRef] [PubMed]

80. Ledoux, A.C.; Perkins, N.D. NF-kB and the cell cycle. Biochem. Soc. Trans. 2014, 42, 76-81. [CrossRef]

81. Guttridge, D.C.; Albanese, C.; Reuther, J.Y.; Pestell, R.G.; Baldwin, A.S. NF-kB controls cell growth and differentiation through transcriptional regulation of cyclin D1. Mol. Cell. Biol. 1999, 19, 5785-5799. [CrossRef]

82. Smith, S.M.; Lyu, Y.L.; Cai, L. NF-kB affects proliferation and invasiveness of breast cancer cells by regulating CD44 expression. PLoS ONE 2014, 9, e106966. [CrossRef]

83. Bassères, D.S.; Ebbs, A.; Levantini, E.; Baldwin, A.S. Requirement of the NF-кB subunit p65/relA for K-Ras-induced lung tumorigenesis. Cancer Res. 2010, 70, 3537-3546. [CrossRef]

84. Finco, T.S.; Westwick, J.K.; Norris, J.L.; Beg, A.A.; Der, C.J.; Baldwin, A.S., Jr. Oncogenic Ha-Ras-induced signaling activates NF-кB transcriptional activity, which is required for cellular transformation. J. Biol. Chem. 1997, 272, 24113-24116. [CrossRef]

85. Taniguchi, K.; Karin, M. NF-кB, inflammation, immunity and cancer: Coming of age. Nat. Rev. Immunol. 2018, 18, 309-324. [CrossRef]

86. Sokolova, O.; Naumann, M. NF-kB signaling in gastric cancer. Toxins 2017, 9, 119. [CrossRef] [PubMed]

87. Kunnumakkara, A.B.; Shabnam, B.; Girisa, S.; Harsha, C.; Banik, K.; Devi, T.B.; Choudhury, R.; Sahu, H.; Parama, D.; Sailo, B.L.; et al. Inflammation, NF-kB, and chronic diseases: How are they linked? Crit. Rev. Immunol. 2020, 40, 1-39. [CrossRef] [PubMed]

88. Zhou, W.; Yang, L.; Nie, L.; Lin, H. Unraveling the molecular mechanisms between inflammation and tumor angiogenesis. Am. J. Cancer Res. 2021, 11, 301-317. [PubMed]

89. Ding, D.; Xi, P.; Zhou, J.; Wang, M.; Cong, Y.-S. Human telomerase reverse transcriptase regulates MMP expression independently of telomerase activity via NF-kB-dependent transcription. FASEB J. 2013, 27, 4375-4383. [CrossRef] [PubMed]

90. Malki, A.; Abu ElRuz, R.; Gupta, I.; Allouch, A.; Vranic, S.; Al Moustafa, A.E. Molecular mechanisms of colon cancer progression and metastasis: Recent insights and advancements. Int. J. Mol. Sci. 2020, 22, 130. [CrossRef]

91. Huang, S.; Pettaway, C.A.; Uehara, H.; Bucana, C.D.; Fidler, I.J. Blockade of NF-kB activity in human prostate cancer cells is associated with suppression of angiogenesis, invasion, and metastasis. Oncogene 2001, 20, 4188-4197. [CrossRef]

92. Stehlik, C.; de Martin, R.; Kumabashiri, I.; Schmid, J.A.; Binder, B.R.; Lipp, J. Nuclear factor (NF)-kB-regulated X-chromosomelinked iap gene expression protects endothelial cells from tumor necrosis factor $\alpha$-induced apoptosis. J. Exp. Med. 1998, 188, 211-216. [CrossRef] [PubMed]

93. Sun, L.; Mathews, L.A.; Cabarcas, S.M.; Zhang, X.; Yang, A.; Zhang, Y.; Young, M.R.; Klarmann, K.D.; Keller, J.R.; Farrar, W.L. Epigenetic regulation of SOX9 by the NF-kB signaling pathway in pancreatic cancer stem cells. Stem Cells 2013, 31, 1454-1466. [CrossRef]

94. Pires, B.R.B.; Mencalha, A.L.; Ferreira, G.M.; do Souza, W.F.; Morgado-Díaz, J.A.; Maia, A.M.; Corrêa, S.; Abdelhay, E.S.F.W. NF-KB is involved in the regulation of EMT genes in breast cancer cells. PLoS ONE 2017, 12, e0169622. [CrossRef] [PubMed]

95. Sinha-Datta, U.; Horikawa, I.; Michishita, E.; Datta, A.; Sigler-Nicot, J.C.; Brown, M.; Kazanji, M.; Barrett, J.C.; Nicot, C. Transcriptional activation of nTERT through the NF-KB pathway in HTLV-I-transformed cells. Blood 2004, 104, $2523-2531$. [CrossRef]

96. De Donatis, G.M.; Le Pape, E.; Pierron, A.; Cheli, Y.; Hofman, V.; Hofman, P.; Allegra, M.; Zahaf, K.; Bahadoran, P.; Rocchi, S.; et al. NF-kB2 induces senescence bypass in melanoma via direct transcriptional activation of EZH2. Oncogene 2016, 35, $2735-2745$. [CrossRef] [PubMed]

97. Isomura, I.; Palmer, S.; Grumont, R.J.; Bunting, K.; Hoyne, G.; Wikinson, N.; Banerjee, A.; Proietto, A.; Gugasyan, R.; Wu, L.; et al. c-Rel is required for the development of thymic Foxp3 ${ }^{+}$regulatory T cells. J. Exp. Med. 2009, 206, 3001-3014. [CrossRef]

98. Porta, C.; Rimoldi, M.; Raes, G.; Brys, L.; Ghezzi, P.; Di Liberto, D.; Dieli, F.; Ghisletti, S.; Natoli, G.; De Baetselier, P.; et al. Tolerance and M2 (alternative) macrophage polarization are related processes orchestrated by p50 nuclear factor kappaB. Proc. Natl. Acad. Sci. USA 2009, 106, 14978-14983. [CrossRef] [PubMed]

99. Lawrence, T. Macrophages and NF-kB in cancer. Curr. Top. Microbiol. Immunol. 2011, 349, 171-184. [PubMed]

100. Antonangeli, F.; Natalini, A.; Chiara Garassino, M.; Sica, A.; Sanotni, A.; Di Rosa, F. Regulation of PD-L1 expression by NF-kB in cancer. Front. Immunol. 2020, 11, 584626. [CrossRef] 
101. Rinkenbaugh, A.L.; Baldwin, A.S. The NF-кB pathway and cancer stem cells. Cells 2016, 5, 16. [CrossRef]

102. Tabruyn, S.P.; Griffioen, A.W. NF-kB: A new player in angiostatic therapy. Angiogenesis 2008, 11, 101-106. [CrossRef]

103. Min, C.; Eddy, S.F.; Sherr, D.H.; Sonenshein, G.E. NF-kB and epithelial to mesenchymal transition of cancer. J. Cell. Biochem. 2008, 104, 733-744. [CrossRef]

104. Ghareghomi, S.; Ahmadian, S.; Zarghami, N.; Kahroba, H. Fundamental insights into the interaction between telomerase/TERT and intracellular signaling pathways. Biochimie 2021, 181, 12-24. [CrossRef] [PubMed]

105. Jing, H.; Lee, S. NF-кB in cellular senescence and cancer treatment. Mol. Cells 2014, 37, 189-195. [CrossRef] [PubMed]

106. Tornatore, L.; Thotakura, A.K.; Bennett, J.; Moretti, M.; Franzoso, G. The nuclear factor kappa B signaling pathway: Integrating metabolism with inflammation. Trends Cell Biol. 2012, 22, 557-566. [CrossRef]

107. Betzler, A.C.; Theodoraki, M.N.; Schuler, P.J.; Döscher, J.; Laban, S.; Hoffmann, T.K.; Brunner, C. NF-kB and its role in checkpoint control. Int. J. Mol. Sci. 2020, 21, 3949. [CrossRef] [PubMed]

108. Seitz, C.S.; Lin, Q.; Deng, H.; Khavari, P.A. Alterations in NF- $k B$ function in transgenic epithelial tissue demonstrate a growth inhibitory role for NF-кB. Proc. Natl. Acad. Sci. USA 1998, 95, 2307-2312. [CrossRef]

109. Gapuzan, M.E.; Schmah, O.; Pollock, A.D.; Hoffmann, A.; Gilmore, T.D. Immortalized embryonic mouse fibroblasts lacking the RelA subunit of transcription factor NF-kB have a malignantly transformed phenotype. Oncogene 2002, 21, 2484-2492. [CrossRef] [PubMed]

110. Chen, F.; CastranovSa, V. Nuclear factor-кB, an unappreciated tumor suppressor. Cancer Res. 2007, 67, 11093-111098. [CrossRef]

111. Carrà, G.; Lingua, M.F.; Maffeo, B.; Taulli, R.; Morotti, A. P53 vs NF-kB: The role of nuclear factor-kappa B in the regulation of p53 activity and vice versa. Cell Mol. Life Sci. 2020, 77, 4449-4458. [CrossRef]

112. Gilmore, T.D.; Garbati, M.R. Inhibition of NF-кB signaling as a strategy in disease therapy. Curr. Top. Microbiol. Immunol. 2011, 349, 245-263.

113. Phelan, J.D.; Young, R.M.; Webster, D.E.; Roulland, S.; Wright, G.W.; Kasbekar, M.; Shaffer, A.L.; Ceribelli, M.; Wang, J.Q.; Schmitz, R.; et al. A multiprotein supercomplex controlling signaling in lymphoma. Nature 2018, 560, 387-391. [CrossRef] [PubMed]

114. Bushwell, J.H. Targeting transcription factors in cancer - from undruggable to reality. Nat. Rev. Cancer 2019, 19, 611-624. [CrossRef] [PubMed]

115. Hofmann, M.H.; Gmachi, M.; Ramharter, J.; Savarese, F.; Gerlach, D.; Marszlaek, J.R.; Sanderson, M.P.; Kessler, D.; Trapani, F.; Arnhof, H. BI-3406, a potent and selective SOS1-KRAS interaction inhibitor, is effective in KRAS-driver cancers through combined MEK inhibition. Cancer Discov. 2021, 11, 142-157. [CrossRef] [PubMed] 